\title{
A Utilitarian Perspective on Business Ethics
}

\author{
Dr. Priyanka Chaudhary, Dr.Vijeta Soni \\ JECRC University Jaipur
}

\begin{abstract}
The recent work of S Jayashree on Morality and the work of S Sadri and S Jayashree on Business Ethics and Corporate Governance form the basis of a philosophical-rationalist-positivist treatment of morals. This paper takes a utilitarian approach since we are living in peripheral capitalist economy where managers are quite self-centred in their approach to their profession. In fact the second edition of Theory and Practice of Managerial Ethics that is due for publication later this year categorically states that Indian managers are very consequentlist in their approach to the ethical dilemma. It is therefore only proper for us to take a similar position since the readership of this journal is professional in nature.

If we were to ask "have you done something, which was against your values, beliefs and moral principles?" The straight away answer to such a question would be a simple NO!

Let us now rephrase this and ask:

- You did not help a person who met with an accident in front of you and was lying on the road waiting for someone to give him assistance?

- Have you ever bribed someone for getting your work done?

- Have you ever discriminated against someone because of his caste, creed, sex or any other thing?

If the answer of any of the above mentioned question is yes then dear friend its time you should revise your definition of values, beliefs and moral principles. We can understand that it is difficult to judge what is right and what is wrong because what is right in one situation can be wrong and improper in another situation.
\end{abstract}

\section{Introduction}

There is a big difference between what you have a right to do and what is right to do, as Justice Potter Stewart had once remarked. Never let your sense of morals get in the way of doing what's right said Issac Asimov. Indeed, man is a social animal. McIver and Page, Percy Cohen, Ralf Dahrendorf, John Rex, Anthony Giddens and several great modern sociologists have reasserted this anthropological fact. Though rules of nature control humans as they control other living beings, man himself has derived certain principles to govern his own individual and group behaviour. These rules, in the form of behavioural standards may differ across cultures and times, but their basic objectives are always mutual existence and peace within the particular community or the social group. By ensuring security and protection of the group these standards helps in the survival of the particular community or a social group and thus its members. These standards of behaviour are called "ethics."

Few socio-biologists argue that humans have biologically inherited capacity to make ethical judgments by evaluating actions as either good or evil. Internally in an organization, apart from the organizational culture, its top leadership and their ideologies also influence ethical orientation of a people. As in the case of individuals, organizations irrespective of their size are also monitored and evaluated by a set of ethical standards. Apart from internal ethical code of conduct, external entities like professional and legal bodies, government and other public interests groups influence the norms of behaviour for organizations. International bodies like United Nations and other non-government organizations like Amnesty International also influence these norms. They try to govern ethical concerns that are globally important by influencing policies and rules framed by the governments.

\section{Meaning of Ethics}

A few years ago, sociologist Raymond Baumhart asked business people, "What does ethics mean to you?" Among their replies were the following: "Ethics has to do with what my feelings tell me is right or wrong." "Ethics has to do with my religious beliefs." "Being ethical is doing what the law requires." "Ethics consists of the standards of behaviour our society accepts." "I don't know what the word means."

These replies might be typical of our own. The meaning of "ethics" is hard to pin down, and the views many people have about ethics are shaky. Like Baumhart's first respondent, many people tend to equate ethics with their feelings. But being ethical is clearly not a matter of following one's feelings. A person following his or her feelings may recoil from doing what is right. In fact, feelings frequently deviate from what is ethical. Nor should one identify ethics with religion. Most religions, of course, advocate high ethical standards. Yet if ethics were confined to religion, then ethics would apply only to religious people. But ethics applies as much to the 
behaviour of the atheist as to that of the saint. Religion can set high ethical standards and can provide intense motivation for ethical behaviour. Ethics, however, cannot be confined to religion nor is it the same as religion.

Being ethical is also not the same as following the law. The law often incorporates ethical standards to which most citizens subscribe. But laws, like feelings, can deviate from what is ethical. Pre-Civil War slavery laws in the US and the apartheid laws of South Africa (before independence) are grotesquely obvious examples of laws that deviate from what is ethical. Finally, being ethical is not the same as doing "whatever society accepts." In any society, most people accept standards that are, in fact, ethical. But standards of behaviour in society can deviate from what is ethical. An entire society can become ethically corrupt. Nazi Germany is a good example of a morally corrupt society as is Idi Amin's Uganda, Pinochet's Chile and Zia's Pakistan.

Moreover, if being ethical were doing "whatever society accepts," then to find out what is ethical, one would have to find out what society accepts. To decide what I should think about abortion, for example, I would have to take a survey of American society and then conform my beliefs to whatever

In the first instance, I have tried to explain you the concept of Business Ethics, its importance in the organization, and arguments against its implementation. Along with that we did a small activity so as to make everything clear. In this paper I shall also talk about morality and moral standards.

Morality is closely linked to ethical behaviour and can be explained in all these ways:

- Morality can be defined as the standards that an individual or a group has about what is right and wrong, or good and evil.

- Moral quality or character; rightness or wrongness, as of an action; the character of being in accord with the principles or standards of right conduct.

- Not imposed from outside, but innate and can even be unconscious. We have a fundamental urge to connect.

As mentioned earlier, whereas Jayashree (2007) seminal work on Morality goes into the philosophy of the topic while we are concerned here with the everyday usage of the concept. Immanuel Kant had divided the universe into the real and the metaphysical worlds placing God in the firmly latter. Georg Hegel created the dialectic of the thesis antithesis and synthesis proclaiming that all truth is relative except the Almighty. Suffice it is to say that all religions deal with that Great Immensity in one form or the other. Sadri (1985) had emphatically stated that God was chased out of heaven by Marx 150 years ago, that Freud had banished Him into the unconscious and Nietzsche had declared Him dead, so the debate was over. But whatever be our position morality is that which helps mankind to keep equilibrium with the larger environment. Ultimately, it's our moral qualities that force us to live in harmony with the unconscious; doing so is the highest form of morality. Morality is individual; the morality of a group decreases as its size increases.

- Morality is an informal public system applying to all rational persons, governing behaviour that affects others, and has the lessening of evil or harm as its goal.

- Morality is a complex of concepts and philosophical beliefs by which an individual determines whether his or her actions are right or wrong. Often, these concepts and beliefs are generalized and codified in a culture or group, and thus serve to regulate the behaviours of its members.

- Conformity to such codification is called morality, and the group may depend on widespread conformity to such codes for its continued existence. A "moral" may refer to a particular principle, usually as informal and general summary of a moral principle, as applied in a given human situation.

Now let us take this brief discourse towards the characteristics of Morality

- To say that morality is a public system incorporates the essential feature that everyone who is subject to moral judgment knows what kinds of actions it prohibits, requires, discourages, encourages, and allows. It also guarantees that it is never irrational to act morally.

- It would take considerably more space than is appropriate here to show that defining morality as a public system that applies to all rational persons also results in morality being a universal guide to behaviour that all rational persons would put forward for governing the behaviour of all moral agents. I should make clear that the claim that all rational persons would put forward this system only follows if limitations are put on the beliefs that rational persons can use and if they are attempting to reach agreement with similarly limited rational persons.

- To say that morality is an informal system means that it has no authoritative judges and decision procedures that provide unique answers to all moral questions. When it is important that disagreements be settled, societies use political and legal systems to supplement morality. These formal systems have the means to provide unique answers, but they do not provide a moral answer to the question. 
Example: An important example of such a moral question is whether, and if so under what conditions, to allow abortion. There is continuing disagreement about this moral question, even though the legal and political system in the United States has provided fairly clear guidelines about the conditions under which medical termination of pregnancy is allowed. Despite this important and controversial issue, morality, like all informal public systems, presupposes overwhelming agreement on most moral questions.

No one thinks it is morally justified to cheat, deceive, injure, or kill simply in order to gain sufficient money to take a fantastic vacation. In the vast majority of moral situations, given agreement on the facts, no one disagrees, but for this very reason, these situations are never discussed. Thus, the over-whelming agreement on most moral matters is often overlooked.

- The claim that morality governs behaviour that affects others is somewhat controversial. Some have claimed that morality governs behaviour that affects only the agent himself/herself.

- Examples of behaviour that supposedly affects only oneself often include taking recreational drugs, and developing one's talents.

- The final characteristic of morality - that it has the lessening of evil or harm as its goal — is also somewhat controversial.

The Utilitarians talk about producing the greatest good as the goal of morality. However they include the lessening of harm as essential to producing the greatest good and almost all of their examples involve the avoiding or preventing of harm.

The question is then raised: When do we hold people morally responsible for their acts and their effects? When the person knowingly and freely performed or brought about an action/effect, which was morally wrong for the person to perform/bring about. When the person knowingly and freely failed to perform or prevent an action/effect, which was morally wrong for the person to fail to perform or prevent.

Moral Responsibility: When a person performs or fails to perform a morally significant action, we sometimes think that he or she is deserving of a particular kind of response. Praise and blame are perhaps the most common forms this reaction takes. For example, one who encounters a car accident may be worthy of praise for having saved a child from inside the burning car, or alternatively, one may be worthy of blame for not having at least used one's cell phone to call for help. To regard such agents as worthy of one of these reactions is to ascribe moral responsibility to them on the basis of what they have done or left undone. (These are examples of otherdirected ascriptions of responsibility. The reaction might also be self-directed, e.g., one can recognize oneself to be blameworthy). Thus, to be morally responsible for something, say an action, is to be worthy of a particular kind of reaction - praise, blame, or something akin to these - for having performed it. Philosophical reflection on moral responsibility has historically relied upon one of two broad interpretations of the concept:

1. The merit-based view, according to which praise or blame would be an appropriate reaction toward the candidate if and only if she merits- in the sense of 'deserves' - such a reaction.

2. The consequentialist view, according to which praise or blame would be appropriate if and only if a reaction of this sort would likely lead to a desired change in the agent and/or her behaviour.

Moral Responsibility is taken for doing something wrong or for wrongfully injuring someone. A judgement about a person's moral responsibility for a wrongful injury is a judgment about the extent to which the person deserves blame or punishment, or should pay restitution for the injury.

Here we are discussing 'Moral Responsibility' as a term that is used to express that a person is to blame for an action. A person is morally responsible only for those acts and their foreseen injurious effects which the person knowingly and freely performed or brought about and which was morally wrong for the person to perform or bring about; or, which the person knowingly and freely failed to perform or prevent and which it was morally wrong for the person to fail to perform or prevent. Several manufacturers of asbestos, for example, were recently judged responsible for the lung diseases of their workers. The judgment was based in part on the finding that the manufacturers had a special duty to warn their workers of the known dangers of working with asbestos, but that they knowingly failed to perform this duty, and the lung diseases were a foreseen injury that they could have prevented had they acted as they had a duty to act.

Two conditions completely eliminate a person's moral responsibility for causing a wrongful injury: Ignorance and Inability, both of which are legitimate people management concerns.

These are called excusing conditions because they fully excuse a person from being held responsible for something. Ignorance of fact generally eliminates moral responsibility completely for the simple reason that a person cannot be obligated to do something over which he or she has no control. Negligently or deliberately created ignorance is an exception to this principle because such ignorance can be controlled. 
Inability can be the result of either internal or external circum-stances that render a person unable to do something or unable to keep from doing something. Inability eliminates responsibility because again a person cannot have any moral obligation to do something over which the person has no control.

In addition to the two excusing conditions that completely remove a person's moral responsibility for a wrong, there are also several mitigating factors that can lessen a person's moral responsibility depending how serious the wrong is.

\section{Mitigating factors include:}

1. A person may be fairly convinced that doing something is wrong, yet may still be doubtful about some important facts, moral standards involved or doubts about how seriously wrong the action is.

2. A person may find it difficult to avoid a certain course of action because he or she is subjected to threats or duress of some sort or because avoiding that course of action will impose heavy costs on the person.

3. A person's responsibility can also be mitigated by circumstances that diminish the person's active involvement in the act that caused or brought about an injury.

The extent to which these three mitigating circumstances can diminish a person's worth is a moot point. In Business Ethics, the concept of "Utilitarianism" is an important one. Authors like Sadri, Jayashree, Chakraborty and Sharma have delved deep into this in their various works over the past decade.

\section{Utilitarianism - It's Meaning and Nature}

The word finds its origins in the works of Jeremy Bentham and William Stanley Jevons two economists who taught at University College, London. In the early 1960s, Ford's position in the automobile market was being heavily eroded by competition from foreign automakers, particularly from Japanese companies making compact fuel-efficient cars. Lee Iaccoca, president of Ford at that time, was desperately trying to regain Ford's share of the automobile market. His strategy centred on quickly designing, manufacturing, and marketing a new car to be called "Pinto". The Pinto was to be a low cost subcompact that would weigh less than 2000 pounds, cost less than $\$ 2000$, and be brought to market in two years instead of normal four. Because the Pinto was a rush project, styling considerations dictated engineering design to a greater degree than usual. In particular, the Pinto's styling required that the gas tank be placed behind the rear axle where it was more vulnerable to being punctured in case of a rear-end collision.

When an early model of the Pinto was crash-tested, it was found that when struck from the rear at 20 miles per hour or more, the gas tank would sometimes rupture and gas would spray out and into the passenger compartment. In a real accident stray sparks might explosively ignite the spraying gasoline and possibly burn any trapped occupants. Ford managers decided, nonetheless, to go ahead with the production of the Pinto for several reasons. First the design met all the applicable legal and government standards then in effect. At the time government regulations required that a gas tank only remain intact in rear-end collision of less than 20 miles per hour. Second, Ford managers felt that the car was comparable in safety to several other cars then being produced by other auto companies. Third, according to an internal cost-benefit study that Ford carried out, the costs of modifying the Pinto would not be balanced by the benefits. The study showed that modifying the gas tank of the 12.5 million autos that would eventually be built would cost about $\$ 11$ a unit for a total of $\$ 137$ million.

On the other hand, statistical data showed that the modification would prevent the loss of about 180 burn deaths, 180 serious burn injuries, and 2100 burned vehicles. At the time the government officially valued a human life at $\$ 200,000$, insurance companies valued a serious burn injury at $\$ 67,000$, and the average residual value on subcompacts was $\$ 700$. So, in monetary terms, the modification would have the benefit of preventing losses with a total value of only $\$ 49.15$ million.

Thus, a modification that would ultimately cost customers $\$ 137$ million (since the cost of modification would be added to the price of the car) would result in the prevention of customer losses valued at only $\$ 49.15$ million. It was not right, the study argued, to spend $\$ 137$ million of society's money to provide a benefit society valued at only $\$ 49.15$ million.

Ford subsequently went ahead with the production of the unmodified Pinto. It is estimated in the decade that followed at least 60 persons died in fiery accidents involving Pintos and that at least twice that many suffered burns over large areas of their bodies, many requiring years of painful skin grafts. Ford eventually phased out the Pinto model.

Utilitarianism holds that actions and policies should be evaluated on the basis of the "benefits" and "costs" they will impose on society. In any situation, the "right" action or policy is the one that will produce the greatest net benefits or the lowest net costs. "Benefits" include both monetary benefits (like income) and nonmonetary benefits (like happiness, satisfaction). "Costs" include both monetary costs (like income losses) and non-monetary costs (like unhappiness, dissatisfaction). The Ford managers estimated only the monetary costs 
and benefits. The utilitarian principle assumes that we can somehow measure and add the quantities of benefits and costs.

$>$ Utilitarianism is an effort to provide an answer to the practical question "What ought a man to do?" Its answer is that he ought to act so as to produce the best consequences possible.

$>$ Utilitarianism proposes that an action is right if it produces the most utility for all persons affected by the action (including the person performing the act).

$>$ Utilitarianism holds that in the final analysis only one action is right - that action whose net benefits are greatest relative to the net benefits of all other possible alternatives.

Finally, Utilitarianism considers both immediate as well as all future costs and benefits of the action taken.

- Utilitarian values have been highly influential in economics. Classical Economists argue that economic behaviour could be explained by assuming that human beings always attempt to maximize their utility (the want satisfying ability in any good or commodity) and that the utilities of commodities can be measured by the prices people are willing to pay for them. Economists proved that in perfectly competitive markets prices gravitate towards an equilibrium (ie. prices do not change, and the demand for a product is equal to its supply). Economists showed that perfectly competitive markets are better than any other market system. Linked closely with utilitarianism is the concept of justice and with it the notion of fairness.

Concept of justice: We hear the cry "Peace and Justice!" from people who would destroy existing societies with fire and sword. Other people fancy that perfect justice might readily be obtained by certain financial rearrangements - as if anything in this world ever could be perfected. Very often we all say that the particular action was not justified. It was not right on the part of that person to treat us like the way he or she did but do you know what is the meaning of justice and fairness? Lets understand the meaning of these two terms. "Justice is the ligament which holds civilized beings and civilized nations together," said Daniel Webster at the funeral of Justice Joseph Story, in 1845. Justice rests on the premise of truth and fairness.

Fairness: This is conformity with rules or standards and ability to make judgments free from discrimination or dishonesty Disputes among individuals in business are often interlaced with references to justice or to fairness. Justice and fairness are essentially comparative. They are concerned with the comparative treatment given to the members of a group when benefits and burdens are distributed, when rules and laws are administered, when members of a group cooperate or compete with each other, and when people are punished for the wrongs they have done or compensated for the wrongs they have suffered. Standards of Justice are generally taken to be more important than utilitarian considerations, however, standards of Justice do not generally override the moral rights of individuals.

Principles of Justice: The most fundamental principle of justice - one that has been widely accepted since it was first defined by Aristotle more than two thousand years ago - is the principle that "equals should be treated equally and unequal unequally." In its contemporary form, this principle is sometimes expressed as follows: "Individuals should be treated the same, unless they differ in ways that are relevant to the situation in which they are involved." For example, if Jack and Jill both do the same work, and there are no relevant differences between them or the work they are doing, then in justice they should be paid the same wages. And if Jack is paid more than Jill simply because he is a man, or because he is white, then we have an injustice - a form of discrimination - because race and sex are not relevant to normal work situations.

There are, however, many differences that we deem as justifiable criteria for treating people differently. For example, we think it is fair and just when a parent gives his own children more attention and care in his private affairs than he gives the children of others; we think it is fair when the person who is first in a line at a theatre is given first choice of theatre tickets; we think it is just when the government gives benefits to the needy that it does not provide to more affluent citizens; we think it is just when some who have done wrong are given punishments that are not meted out to others who have done nothing wrong; and we think it is fair when those who exert more efforts or who make a greater contribution to a project receive more benefits from the project than others. These criteria - need, desert, contribution, and effort-we acknowledge as justifying differential treatment, then, are numerous.

On the other hand, there are also criteria that we believe are not justifiable grounds for giving people different treatment. In the world of work, for example, we generally hold that it is unjust to give individual's special treatment on the basis of age, sex, race, or their religious preferences. If the judge's nephew receives a suspended sentence for armed robbery when another offender unrelated to the judge goes to jail for the same crime, or the brother of the Director of Public Works gets the million dollar contract to install sprinklers on the municipal golf course despite lower bids from other contractors, we say that it's unfair. We also believe it isn't 
fair when a person is punished for something over which he or she had no control, or isn't compensated for a harm he or she suffered. And the people involved in the "brown lung hearings" felt that it wasn't fair that some diseases were provided with disability compensation, while other similar diseases weren't.

Issues involving Justice and fairness are usually divided into three categories and all of these are crucial to the practice of HR:

- Distributive Justice (concerned with the fair distribution of societies benefits and burdens),

- Retributive Justice (the just imposition of punishments and penalties upon those who do wrong),

- Compensatory Justice, (the just way of compensating people for what they had lost when they were wronged by others).

To sum up, the Indian HR Manager operates on a utilitarian paradigm. Perhaps he / she often learns and imbibes it from the Director of the B School he/she went to. The Director of a B School is of three kinds: the administrative director, the academic director and the two in one director. The administrative director is a pen pusher and a master politician. The academic director is a hard-core teacher and researcher. The two in one is a rare variety when you have a director who is both a scholar and an administrator. But most Directors of B Schools of the administrative variety are Utilitarians: before they take action they ask what is in it for me or will it help many? How that many is defined is essentially different for each person. Often the manager does not even know what this term "for the general good" really means. He blindly imitates the Director of his/her B School. Hence this discourse was directed to clear the air of the manager and clarify an important managerial position from an expert viewpoint.

Thus Business Ethics helps us to study business situations, activities and decisions where issues of morally right and morally wrong are addressed. The three levels at which the Business Ethics operates are:

\begin{tabular}{|c|c|}
\hline Levels & Focus Area \\
\hline Micro Level & Individual \\
\hline Meso Level & Group \\
\hline Macro Level & Society \\
\hline
\end{tabular}

These three levels help us to understand the business ethics, ranging from the behaviour and responsibility of managers, workers and businessmen to the morality of corporation, up to the evaluation of governmental and public policies.

\section{Books:}

[1] Chakraborty S K, Management by values: Towards Cultural Congruence (Oxford University Press, Bombay, 1991)

[2] Chakraborty S K, Ethics in Management (Oxford University Press, Dehli, 1994)

[3] Donaldson T, The Ethics of International Business (Oxford University Press, New York, 1989)

[4] Donaldson T and P H Werhane, Ethical Issues in Business (Prentice Hall, Sydney, 1988)

[5] Sadri S and Jayashree S, Business Ethics and Corporate Governance (Current Publications, Agra, 2011) 